\title{
Confirmation of Pteragogus trispilus Randall, 2013 (Labridae) with an Additional Record from Iskenderun Bay (Eastern Mediterranean, Turkey)
}

\author{
Deniz ERGÜDEN1* Ferhat KABAKLI'1, Sibel ALAGÖZ ERGÜDEN², Ayhan ALTUN¹
}

${ }^{1}$ Faculty of Marine Science and Technology, University of Iskenderun Technical, TR 31220 Iskenderun, Hatay, Turkey

${ }^{2}$ Vocational School, Imamoglu University of Cukurova, TR 01700 Imamoglu, Adana, Turkey

ORCID ID: Deniz ERGÜDEN: https://orcid.org/0000-0002-2597-2151; Ferhat KABAKLI: https://orcid.org/0000-0001-7738-3597; Sibel ALAGÖZ ERGÜDEN: https://orcid.org/0000-0003-4363-433X; Ayhan ALTUN: https://orcid.org/0000-0002-1921-2498

\begin{tabular}{l} 
Received: $30.01 .2019 \quad$ Accepted: 26.03.2019 Published online: 30.06.2019 Issue published: 30.06 .2019 \\
\hline Abstract: Pteragogus trispilus Randall, 2013, previously known as Pteragogus pelycus, is a lessepsian migrant to the eastern \\
Mediterranean Sea. Reporting two specimens, this paper confirms the occurrence of the species in Iskenderun Bay (Eastern \\
Mediterranean coast of Turkey) in addition to the previous reports from the Mediterranean coast of Turkey. This report is the \\
first observation for the location and; thus, fills a gap in the distribution range of the species. All measurements and counts as \\
well as morphological and color descriptions of P. trispilus are given in the study.
\end{tabular}

Keywords: Labridae, Iskenderun coast, eastern Mediterranean, Turkey

\section{İskenderun Körfezi (Doğu Akdeniz, Turkiye)'nden İlave Kaydı ile Pteragogus trispilus Randall, 2013 (Labridae)'un Teyidi}

Öz: Daha önce Pteragogus pelycus olarak bilinen Pteragogus trispilus Randall, 2013, Doğu Akdeniz'deki lessepsiyen göçmen bir türdür. Bu çalışmada Türkiye' nin Doğu Akdeniz kıyısından önceki kayıtlara ek olarak, İskenderun Körfezi (Türkiye'nin Doğu Akdeniz kıyıları)'nden elde edilen iki bireyi ile türün varlığı bir kez daha kanıtlanmıştır. Bu rapor İskenderun Körfezi için yapılan ilk gözlemdir ve türün dağılım aralığındaki bir boşluğu doldurmaktadır. P. trispilus'un morfolojik ve renk tanımlarının yanı sıra tüm ölçümler ve sayımlar metin içerisinde verilmiştir.

Anahtar kelimeler: Labridae, İskenderun sahili, Doğu Akdeniz, Türkiye

\section{Introduction}

The opening of the Suez Canal in 1869 resulted in the introduction of Red Sea species to the Mediterranean Sea. This act of migration was called as 'Lessepsian migration' by Ferdinand de Lesseps. The penetration and invasion increased following the construction of the Aswan Dam in 1970 (Galil, 1993). Eventually, this phenomenon became the main reason of the increase in the faunal divergence in the Mediterranean Sea (Quignard \& Tomasini, 2000; Golani, Orsi-Relini, Massuti, \& Quignard, 2002).

Pteragogus trispilus Randall, 2013 is a lessepsian migrant to eastern Mediterranean Sea (Corsini-Foka et al., 2015; Iglésias \& Frotté, 2015; Bilecenoglu, 2016) and now widespread throughout the region.

The first record of the species in the Mediterranean was the report of an observation made in 1991 along the coast of Israel (Golani \& Sonin, 1992). Further reports of the occurrence of the species in the Mediterranean Sea were made from Rhodes (Corsini \& Economidis, 1999; Kalogirou, Corsini-Foka, Sioulas, Wennhage, \& Pihl, 2010; Kalogirou, Wennhage, \& Pihl, 2012), Turkey (Taşkavak, Bilecenoglu, Başusta, \& Mater, 2000; Öğretmen, Yilmaz, \& Torcu Koc, 2005; Öz, Okuş, \& Ahsen, 2007; Bilecenoglu, 2010), Cyprus (Kaya, Bilecenoglu, \& Golani, 2000), Lebanon (Harmelin-Vivien, Bitar, Harmelin, \& Monestiez, 2005), Egypt (Halim \& Rizkalla, 2011; Azzurro, Milazzo \&
Maynou, 2012), the Hellenic Seas (Sterioti, 2012), Syria (Soliman, Ali, Saad, Reynaud, \& Capapé, 2014), and Tunisia (Hamed, Miled-Fathalli, \& Chakroun-Marzouk, 2018).

Today, $P$. trispilus is considered as a successful invader distributed throughout the Mediterranean Sea (EastMed, 2010; Bilecenoglu, 2016). This study gives the details obtained from two specimens, one of which was encountered in its natural habitat during an underwater observation. In this paper, the occurence of $P$. trispilus is reported for the first time from Iskenderun Bay, adding another brick in the wall to fill the gap in the geographic distribution of this species in eastern Mediterranean.

\section{Material and Methods}

The first specimen of $P$. trispilus was photographed at a depth of $3 \mathrm{~m}$ during a SCUBA diving expedition in Konacı/Arsuz (Iskenderun Bay) on 17th of September 2012. The second specimen of $P$. trispilus was a male captured in Gökmeydan (Coordinate: $36^{\circ} 26^{\prime} \mathrm{N}, 35^{\circ} 54^{\prime} \mathrm{E}$ ), Iskenderun Bay on 13rd of April 2018. This specimen was caught on rocky bottoms, partially covered with algae and sea grass, by shrimp trammel net of $22 \mathrm{~mm}$ mesh size (Fig. 1 and Fig. 2). It was immediately photographed upon the capture and transported to the laboratory for more detailed examination. Morphometric measurements of the male specimen were made to the nearest $0.1 \mathrm{~mm}$ using 
digital caliper and weighed to the nearest gram (g). The specimen is deposited in the Museum of the Faculty of Marine Sciences and Technology, Iskenderun Technical University with catalogue number MSM-PIS/2018-3. Distribution of the $P$. trispilus in the Red Sea and the Mediterranean Sea has given according to previous capture records and the present report from Iskenderun Bay (Fig. 3).

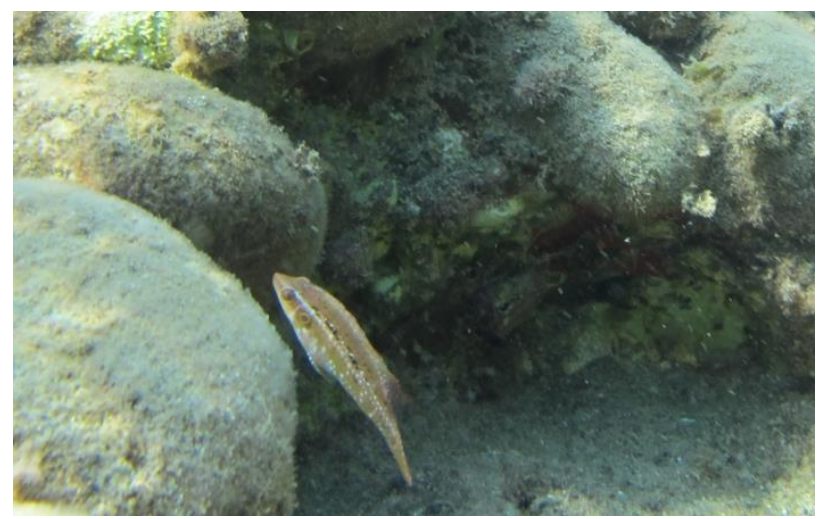

Figure 1: Underwater observation of Pteragogus trispilus in Konacık (Arsuz), Iskenderun Bay (Photo: Deniz Ergüden)

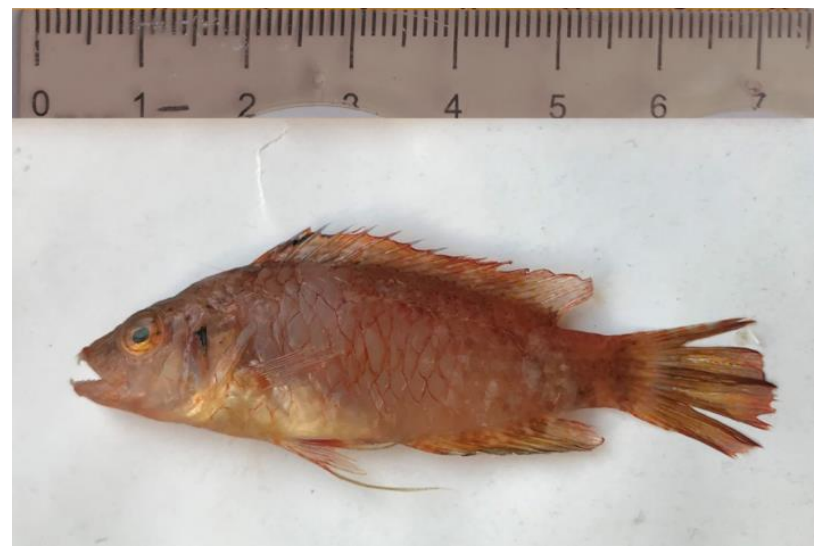

Figure 2: A male specimen of Pteragogus trispilus, $66.5 \mathrm{~mm} \mathrm{TL}$, from Iskenderun Bay (MSM-PIS/2018-3)

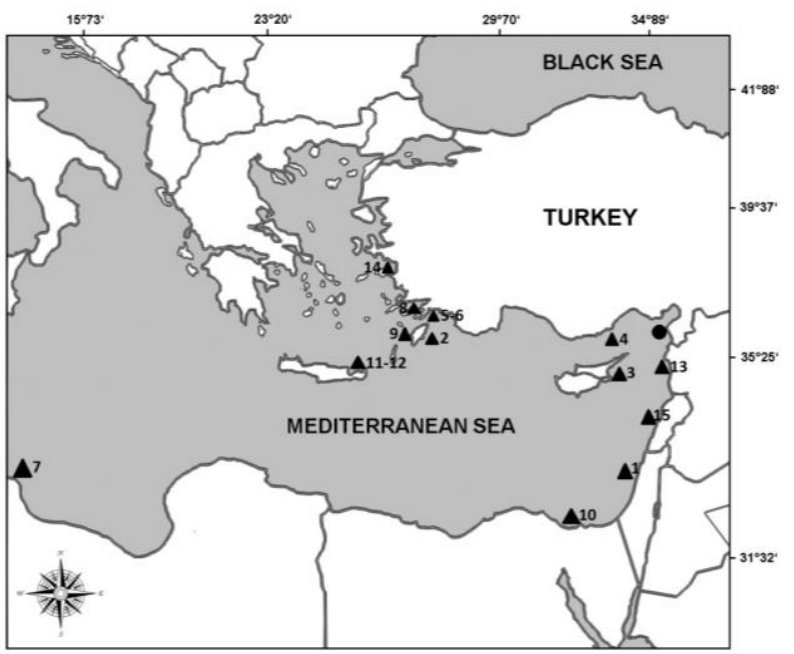

Figure 3: Map showing the capture sites of Pteragogus trispilus in the Mediterranean Sea.
$\boldsymbol{\Lambda}$, Previous record; • Present record; 1, Haifa Bay, Israel; 2, Rhodes Island (Aegean Sea), Greece; 3, Magosa Bay, Cyprus; 4, Ovacık, Mersin Bay, Turkey; 5, Fethiye, Gökova Bay, Turkey; 6, Gökova Bay (Southern Aegean Sea), Turkey; 7, Lebanon coast; 8, Datça-Bozburun Peninsula, Turkey; 9, Coast of Rhodes, Greece; 10, Alexandria coast, Egypt; 11-12, Heraklion Bay (Cretean Sea), Greece; 13, off Tartous Harbour, Syria; 14, Kuşadası Bay, Aegean Sea, Turkey; 15, Gulf of Tunis, Tunisia

\section{Results}

The body of the P. trispilus is compressed and covered with large cycloid scales. Mouth terminal, slightly oblique, the maxilla extending posteriorly to a vertical at posterior edge of pupil; two pairs of large recurved canine teeth place anteriorly in jaw. The second pair is large and out curved. The previous reports of the P. trispilus from the Mediterranean Sea are given in Table 1 together with the findings of the present study.

The main diagnostic characters and morphometric measurements of the captured male specimen of $P$. trispilus are given in millimeters: the specimen was $66.5 \mathrm{~mm}$ in total length and $50.5 \mathrm{~mm}$ in standard length, and $5.39 \mathrm{~g}$ in total weight. The other morphometric data of the male specimen obtained from fishing was given in Table 2 and the compared to previous reports from the Red Sea (Golani \& Sonin, 1992), Syrian coast (Soliman, Ali, Saad, Reynaud, \& Capapé, 2014) and the central Mediterranean Sea, the Gulf of Tunis (Hamed, Miled-Fathalli, \& ChakrounMarzouk, 2018).

The color of the specimen was mostly light brownreddish; an oblique elliptical black spot on opercula, broadly rimmed in yellow; a vertical white streak to each side of posterior edge of pre-opercula; scattered small black spots behind eye and on nape; pupil rimmed with orange, the rest of iris with seven spoke-like dark lines; lateral line with black dots and dashes and white dots; median fins olivaceous with white dots on rays, oblique white lines on spinous portion ventral part of head and posterior opercula of male suffused with orange.

\section{Discussion}

The species previously was mistaken as Pteragogus pelycus which is claimed not to inhabit in the Mediterranean waters (Randall, 2013). Pteragogus trispilus is a small noncommercial fish species typically inhabits at bottoms with detached brown algae or small coral patches and rocks in coastal areas. Although Randall (2013) claimed that, the species is usually found at 9-28 $\mathrm{m}$ depths. Golani \& Sonin, (1992) reported the trawling of the species from depths of $32-80 \mathrm{~m}$. However, the first specimen reported in this study was observed at $3 \mathrm{~m}$ depth in its natural habitat in Konacik (Arsuz) on rocky and sandy bottoms, partially covered with algae, during a SCUBA diving expedition (Fig. 1). The second one was a male specimen caught at a depth of $22 \mathrm{~m}$ from Gökmeydan (Arsuz) by a shrimp trammel net (mesh size $22 \mathrm{~mm}$ ). This depth range is in accordance with literature (Randall, 2013). However, with this finding vertical distribution range of the species should be revised as 3-80 m.

Pteragogus trispilus is distinguished from the other cogeneric species, P. pelycus, by having 13 simple dorsalfin rays (versus 12-13), 13 branched pectoral fin rays (versus 12), very long pelvic fins, reaching well posterior of anal fin, and rounded caudal fin. Besides, P. trispilus 
have a straight dorsal profile of the head compared to the very strong concavity in the dorsal profile of the head of adult $P$. pelycus. The interorbital of $P$. trispilus is convex whereas it is nearly flat in adult $P$. pelycus. Iris of the eye of an adult $P$. trispilus has seven spoke-like short lines instead of small dark spots; the shape of the ocellus on the opercula is smaller and different from that of $P$. pelycus. There is a black spot on each of the first three membranes of dorsal fin (Randall, 2013). However, black spots in $P$. pelycus are on the upper part of the first 2-4 inter spinous dorsal membrane.

Table 1. Records of Pteragogus trispilus from Mediterranean Sea covering the period 1992-2018.

\begin{tabular}{|c|c|c|c|c|c|c|}
\hline References & $\begin{array}{l}\text { Number of } \\
\text { Samples }\end{array}$ & $\begin{array}{l}\text { Record } \\
\text { Date }\end{array}$ & Location & Sampling Gear & Depth & $\begin{array}{l}\text { Length, TL } \\
(\mathrm{mm})\end{array}$ \\
\hline Golani and Sonin (1992) & 2 & 16.07.1991 & Haifa Bay, Israel & Trawl-net & $32-80$ & $52.1-60.5^{*}$ \\
\hline $\begin{array}{l}\text { Corsini and Economidis } \\
\text { (1999) }\end{array}$ & $\begin{array}{l}1 \\
1 \\
1 \\
1 \\
2\end{array}$ & $\begin{array}{l}03.09 .1992 \\
21.10 .1993 \\
18.10 .1994 \\
26.01 .1995 \\
01.03 .1994\end{array}$ & $\begin{array}{l}\text { Rhodes Island } \\
\text { (Aegean Sea), } \\
\text { Greece }\end{array}$ & $\begin{array}{l}\text { Fishing Rod } \\
\text { Trawl-net } \\
\text { Trawl-net } \\
\text { Trawl-net } \\
\text { Trawl-net }\end{array}$ & $\begin{array}{l}10 \\
100 \\
- \\
- \\
-\end{array}$ & $\begin{array}{l}80.8^{*} \\
77.6^{*} \\
58.1^{*} \\
78.6^{*} \\
54.9-66.1^{*}\end{array}$ \\
\hline Kaya et al. (2000) & 2 & 17.05.1997 & $\begin{array}{l}\text { Magosa Bay, } \\
\text { Cyprus }\end{array}$ & Trawl-net & $32-35$ & $64.8-74.9$ \\
\hline Taşkavak et al. (2000) & 2 & 24.08 .1998 & $\begin{array}{l}\text { Ovacik, Mersin } \\
\text { Bay, Turkey }\end{array}$ & Hand net & 1 & $75.3^{*}$ \\
\hline Bilecenoglu et al. (2002) & 1 & 2000 & $\begin{array}{l}\text { Fethiye, Gokova } \\
\text { Bay, Turkey }\end{array}$ & Visual observation & - & 5 \\
\hline Ögretmen et al. (2005) & 2 & 2000-2001 & $\begin{array}{l}\text { Gökova Bay } \\
\text { (Southern } \\
\text { Aegean Sea), } \\
\text { Turkey }\end{array}$ & Gill net & - & $65-71$ \\
\hline $\begin{array}{l}\text { Harmelin-Vivien et al. } \\
(2005)\end{array}$ & $>1$ & 2001 & $\begin{array}{l}\text { Lebanon Coast } \\
\text { (eastern } \\
\text { Mediterranean } \\
\text { Sea) }\end{array}$ & Visual observation & $0-32$ & - \\
\hline Öz et al. (2007) & 1 & 16.09 .2002 & $\begin{array}{l}\text { Datça-Bozburun } \\
\text { Peninsula, } \\
\text { Turkey }\end{array}$ & Visual observation & $6-15$ & - \\
\hline Kalogirou et al. (2010) & $>3$ & 2008 & $\begin{array}{l}\text { Coast of Rhodes, } \\
\text { Greece }\end{array}$ & Purse seine & $5-35$ & - \\
\hline Azzurro et al. (2012) & 1 & 02.07.2010 & $\begin{array}{l}\text { Alexandria coast, } \\
\text { Egypt }\end{array}$ & Gill net & $15-20$ & 130 \\
\hline Sterioti (2012) & 2 & $\begin{array}{l}23.08 .2015 \\
27.09 .2011\end{array}$ & $\begin{array}{l}\text { Heraklion } \\
\text { Bay (Cretean } \\
\text { Sea), Greece } \\
\text { off }\end{array}$ & Trawl & $15-33$ & 75 \\
\hline Soliman et al. (2014) & 1 & 15.02 .2014 & $\begin{array}{l}\text { TartousHarbour, } \\
\text { Syria }\end{array}$ & Bottom cage net & 38 & 93 \\
\hline Yapici et al. (2015) & 1 & 04.06 .2014 & $\begin{array}{l}\text { Kuşadası Bay, } \\
\text { eastern Aegean } \\
\text { Sea, Turkey }\end{array}$ & Trammel net & 25 & 83 \\
\hline Hamed et al. (2018) & 1 & 07.02.2016 & $\begin{array}{l}\text { Gulf of Tunis, } \\
\text { Tunisia }\end{array}$ & Gill net & - & 113 \\
\hline Present study & 1 & 17.09.2012 & $\begin{array}{l}\text { Konacık (Arsuz), } \\
\text { Iskenderun Bay, } \\
\text { Turkey }\end{array}$ & Visual observation & 3 & - \\
\hline Present study & 1 & 13.04 .2018 & $\begin{array}{l}\text { Gokmeydan, } \\
\text { Iskenderun Bay, } \\
\text { Turkey }\end{array}$ & Trammel net & 22 & 66.5 \\
\hline
\end{tabular}

*Standard Length (SL)

In the present study, all measurements, counts, and morphological characters agree with those of Randall's (1981 and 2013). As indicated by Randall (1981), the second ray of the pelvic fin is extended and reaches to about the end of the anal fin in males, but it is shorter in females. In males, the forehead is high and convex is above the eye 
while the snout is slightly turned up. However, the dorsal profile of the head of females, in general, is straight and less then pronounced than in male (Corsini \& Economidis, 1999).

The native range of this species includes western Indian Ocean to the Red Sea (Golani, Orsi-Relini, Massuti, \& Quignard, 2002), the eastern coast of Africa southwards to Durban, South Africa and, Madagascar, and adjacent Indian Ocean Islands (Randall, 2013). P. trispilus inhabiting in the Mediterranean Sea feeds on invertebrates strictly related to the grass niches (Corsini \& Economidis, 1999; Kalogirou, Wennhage \& Pihl, 2012). Similarly, the male specimen observed during diving was naturally inhabiting among algae communities (Corallina officinalis, Jania rubens and Padina pavonica) on the rocks.

Table 2: Measurements and counts of Pteragogus trispilus compared with three previous records

\begin{tabular}{|c|c|c|c|c|}
\hline Metric (mm) & Present study & $\begin{array}{l}\text { Golani and } \\
\text { Sonin (1992) }\end{array}$ & Soliman et al. (2014) & Hamed et al. (2018) \\
\hline Number & $n=1$ & $n=2$ & $n=2$ & $n=1$ \\
\hline Total length (TL) & 66.5 & - & $93-92$ & 113 \\
\hline Standard length (SL) & 50.5 & $52.1-60.5$ & $75-74$ & 86 \\
\hline Head length (HL) & 18.8 & $35.7-37.2^{*}$ & $21-21$ & 32 \\
\hline Body depth & 18.2 & $32.5-32.6^{*}$ & $28-28$ & 31 \\
\hline Pre-dorsal fin length & 18.0 & - & $24-23$ & 30 \\
\hline Pre-pectoral fin length & 1.78 & - & $25-23$ & 29 \\
\hline Pre-pelvic length & 19.4 & - & $25-25$ & 33 \\
\hline Pre-anal fin length & 32.1 & - & $42-41$ & 52 \\
\hline Caudal fin length & 16.5 & - & - & 28 \\
\hline Caudal peduncle length & 3.7 & - & $10-10$ & 11 \\
\hline Eye diameter & 3.5 & - & 6-6 & 6 \\
\hline Jaw length & 5.8 & - & 8-8 & 10 \\
\hline Pre-orbital length & 6.0 & - & - & 10 \\
\hline Post-orbital length & 9.0 & - & - & 15 \\
\hline Interorbitaldistance & 4.0 & - & $4-4$ & 7 \\
\hline Dorsal fin ray & 31.2 & - & $54-52$ & 53 \\
\hline Anal fin ray & 12.4 & - & $28-29$ & 21 \\
\hline Pectoralfin ray & 13.1 & - & $14-15$ & 23 \\
\hline Pelvicfin ray & 23.5 & - & $37-32$ & 36 \\
\hline \multicolumn{5}{|l|}{ Meristic } \\
\hline Dorsalfin ray & $X I+9$ & XI + 9 (XI + 8-9) & $\mathrm{XI}+9-\mathrm{XI}+8$ & XI + 9 \\
\hline Anal fin ray & $\mathrm{III}+9$ & III + 9 (III+ 8-9) & $\mathrm{III}+8-\mathrm{III}+9$ & III + 9 \\
\hline Pectoral fin ray & 13 & $13(13-14)$ & $13-13$ & 13 \\
\hline Pelvic fin ray & $I+5$ & $I+5$ & $I+5$ & $\mathrm{I}+5$ \\
\hline Caudal fin ray & 14 & - & $13-12$ & - \\
\hline Weight & 5.39 & - & $11.61-10.92$ & 19.13 \\
\hline
\end{tabular}

*Percentage of SL

Surveys conducted on lessepsian migrants in Turkish waters have increased since 1994 (Gücü, Bingel, Avsar, \& Uysal, 1994; Bilecenoglu, 2010; Ergüden \& Turan, 2013; Ergüden, Gürlek, \& Turan, 2018). Nevertheless, further research is required to reveal details about the habitat's requirements for the establishment of non-indigenous species in the area. Besides, future collaboration between researchers and fishermen should be encouraged for the early detection of recent penetration of non-native species into the Mediterranean marine waters.

\section{References}

Azzurro, E., Milazzo, M., \& Maynou, F. (2012). First confirmed record of the Lessepsian migrant Pteragogus pelycus Randall, 1981 (Teleostei: Labridae) for the North African coasts. Bioinvasion Records, 1, 45-48.
Bilecenoglu, M. (2010). Alien marine fishes of Turkey - an updated review. In D. Golani \& B. Appelbaum-Golani (Eds.), Fish invasions of the Mediterranean Sea: change and renewal (pp. 189-217). Sofia-Moscow, Russia, Pensoft Publishers., 332 pp.

Bilecenoglu, M. (2016). Demersal lessepsian fish assemblage structure in the northern Levant and Aegean Seas. Journal of the Black Sea/Mediterranean Environment, 22, 46-59.

Bilecenoglu, M., Taşkavak, E., Mater, S., \& Kaya, M. (2002). Checklist of the marine fishes of Turkey. Zootaxa, 113, 1-194.

Corsini, M., \& Economidis, P.S. (1999). Distribution extension of two Lessepsian migrants found in the marine area of the Island of Rhodes (Aegean Sea, Greece). Cybium, 23, 195-199.

Corsini-Foka, M., Zenetos, A., Crocetta, F., Çinar, M.E., Koçak, F., Golani, D., Stelios Katsanevakis, S., ... E Roy, H. (2015). Inventory of alien and cryptogenic species of the Dodecanese (Aegean Sea, Greece): collaboration through COST action training school. Management of Biological Invasions, 6, 351-366. 
EastMed, (2010). Report of the Sub-Regional Technical meeting on the Lessepsian migration and its impact on Eastern Mediterranean fishery. GCP/INT/041/EC - GRE - ITA/TD-04.

Ergüden, D., \& Turan, C. (2013). Recent developments in the fish fauna of Iskenderun and Mersin Bay. Research Journal of Biological Sciences, 6(1), $17-22$

Ergüden, D., Gürlek, M., \& Turan, C. (2018). Current status of alien fish fauna with Indo-Pacific and Atlantic origin distributed at the south coast of Turkey. Duzce University Journal of Science E Technology, 6(4), 818-836.

Galil, B.S. (1993). Lessepsian migration: New findings on the foremost anthropogenic change in the Levant Basin fauna. In NFR Della Croce (Ed.), Symposium Mediterranean Seas 2000 (pp. 307-318). Santa Margherita Ligure, Italy.

Golani, D., \& Sonin, O. (1992). New records of the Red Sea fishes, Pterois miles (Scorpaenidae) and Pteragogus pelycus (Labridae) from the eastern Mediterranean Sea. Japanese Journal of Ichthyology, 39(2), 167-169.

Golani, D., Orsi-Relini, L., Massuti, E., \& Quignard, J.P. (2002). CIESM Atlas of exotic Species in the Mediterranean. Fishes. Vol 1. Monaco, CIESM Publisher., 256 pp.

Gücü, A.C., Bingel, F., Avsar, D., \& Uysal, N. (1994). Distribution and occurrence of Red Sea fish at the Turkish Mediterranean coast - northern Cilician Basin. Acta Adriatica, 34(1/2), 103-113.

Halim, Y., \& Rizkalla, S. (2011). Aliens in Egyptian Mediterranean waters. A checklist of Erythrean fish with new records. Mediterranean Marine Science, 12, 479-490.

Hamed, O., Miled-Fathalli, N., \& Chakroun-Marzouk, N. (2018). First record of the Lessepsian migrant Pteragogus trispilus Randall, 2013 (Osteichthyes: Labridae) off the Tunisian coasts, Central Mediterranean Sea. Cahiers de Biologie Marine, 59, 115-119.

Harmelin-Vivien, M.L., Bitar, G., Harmelin, J.J., \& Monestiez, P. (2005). The littoral fish community of the Lebanese rocky coast (eastern Mediterranean Sea) with emphasis on Red Sea immigrants. Biological Invasions, 7, 625-637.

Iglésias, S., \& Frotté, L. (2015). Alien marine fishes in Cyprus: update and new records. Aquatic Invasion, 10, 425-438.

Kalogirou, S., Corsini-Foka, M., Sioulas, A., Wennhage, H., \& Pihl, L. (2010). Diversity, structure and function of fish assemblages associated with Posidonia oceanica beds in an area of the eastern Mediterranean Sea and the role of non-indigenous species. Journal of Fish Biology, 77, 2338-2357.

Kalogirou, S., Wennhage, H., \& Pihl, L. (2012). Non-indigenous species in Mediterranean fish assemblages: Contrasting feeding guilds of Posidonia oceanica meadows and sandy habitats. Estuarine, Coastal Shelf Science, 96, 209-218.

Kaya, M., Bilecenoglu, M., \& Golani, D. (2000). New record of a Lessepsian migrant Pteragogus pelycus Randall, 1981 (Teleostei: Labridae) for Northern Cyprus. Zoology in the Middle East, 20, 65-68.

Öğretmen, F., Yilmaz, F., \& Torcu Koc, H. (2005). An investigation on fishes of Gokova Bay (Southern Aegean Sea). Journal of Balikesir University Institute of Science Technology, 7, 19-36.

Öz, M.I., Okuş, E., \& Ahsen, Y. (2007). Notes on the Erythrean alien fishes of Datca-Bozburun Peninsula - a specially protected area in the southeastern Aegean Sea (Turkey). İstanbul, Turkey, Rapport Commission international Mer Méditerranée, 563 pp.

Quignard, J.P., \& Tomasini, J.A. (2000). Mediterranean fish biodiversity. Biologia Marina Mediterranea, 7(3), 1-66.

Randall, J. (1981). Two new species and six new records of labrid fishes from the Red Sea. Senckenbergiana Maritima, 13(1/3), 79-109.

Randall, J.E. (2013). Seven new species of labrid fishes (Coris, Iniistius, Macropharyngodon, Novaculops, and Pteragogus) from the Western Indian Ocean. Journal of Ocean Science Foundation, 7, 1-43.

Soliman, A., Ali, M., Saad, A., Reynaud, C., \& Capapé, C. (2014). First records of sideburn wrasse Pteragogus pelycus (Osteichthyes: Labridae) off the Syrian coast (eastern Mediterranean). Annales Series Histories Naturalis, 24, 23-28.

Sterioti, A. (2012). Pteragogus pelycus (Randall, 1981) in the Cretan Sea. New Mediterranean Biodiversity Records (December 2012). Mediterranean Marine Science, 13, 312-327.

Taşkavak, E., Bilecenoglu, M., Başusta, N., \& Mater, S. (2000). Occurrence of Pteragogus pelycus Randall, 1981 (Teleostei: Labridae) and Petroscirtes ancylodon Rüppell, 1838 (Teleostei: Blennidae) at the eastern Mediterranean coast of Turkey. Acta Adriatica, 41, 53-58.

Yapici, H.H., Yapici, S., Agdamar, S., \& Acar, U. (2015). Occurrence of the Erythrean invader Pteragogus pelycus Randall, 1981 (Teleostei: Labridae) in the eastern Aegean Sea. Journal of Applied Ichthyology, 31, 538-540. 